\title{
Conveyor Belts for Societal Transformation
}

\author{
Marco A Robledo* \\ Associate Professor of the Department of Business Economics, University of the Balearic Islands, Spain
}

Submission: April 24, 2018; Published: June 20, 2018

*Corresponding author: Marco A Robledo, Associate Professor of the Department of Business Economics, University of the Balearic Islands, Spain, Email: marco.robledo@uib.es

Keywords: Conveyor Belts; Societal; Transformation; Predictable stages; Molecules; Ethics; Values; Psychology; Biochemistry; Egocentric; World centric; Atoms; Ecosystems; Conveyor belts; Emotions; Education

\section{Opinion}

Einstein notoriously said that we cannot solve our problems with the same thinking we used when we created them. The kind of world I would like to live in demands significant changes. Those anges will not happen until a majority of the people working towards them are coming out of a higher level of consciousness to the one that has led to the state we are in now. Laloux (2014: 5) considers that a precondition for our survival: "the very survival of many species, ecosystems, and perhaps the human race itself hinges on our ability to move to higher forms of consciousness and from there collaborate in new ways to heal our relationship with the world and the damage we've caused."

Systematic cross-cultural analysis reveals that transformation follows an invariant and predictable developmental pattern. It follows a sequence where each higher developmental stage transcends and includes (or unfolds and enfolds) the stage that preceded it (just as organisms transcend and include cells, which transcend and include molecules, which transcend and include atoms). This process of unfoldment and enfoldment reveals a natural, nested hierarchy of developmental progression.

The first researcher to notice that was Jean Piaget (18961980), who showed in a series of experiments that as children grow, the way they think advances through predictable stages. At each higher stage, children could think in more complex and sophisticated ways, and they were able to deal with increasingly difficult problems.

For a long time, it was assumed that once you reach adulthood, these stages of development would stop. Today it is generally accepted that developmental stages continue into adulthood. Thus, adulthood is not a destination you reach at some point and then you are done, as it used to be believed. It is a never-ending transitioning process to higher stages of development. Whereas children move smoothly and rapidly through the stages, an adult's pace of development is not as predictable and it can slow down dramatically, to the point of plateauing. In addition, while a child's development appears to happen automatically, so you are in your terrible twos or in your sweet sixteen, adults cannot simply sit back and wait until they turn thirty to reach a new level of development; they need to work to keep growing. Graves (2005: 29) puts it this way:

"The psychology of the adult human being is an unfolding, ever-emergent process marked by subordination of older behaviour systems to newer, higher-order systems. The mature person tends to change his psychology continuously as the conditions of his existence change. Each successive stage or level of existence is a state through which people may pass on the way to other states of equilibrium. When a person is centralized in one of the states of equilibrium, he has a psychology which is particular to that state. His emotions, ethics and values, biochemistry, state of neurological activation, learning systems, preference for education, management and psychotherapy are all appropriate to that state" [1].

Following Piaget's pioneering work, the stages of development have been studied by developmental psychologists like Jean Piaget, Lawrence Kohlberg, Carol Gilligan, Abraham Maslow, Jean Gebser and Clare Graves and sophisticated models of development have been created to describe them (including Maslow's hierarchy of needs, Kohlberg's stages of moral development, Graves' emergent cyclic levels of existence, Beck and Cowan's spiral dynamics, Loevinger's stages of ego development, Cook-Greuter's EDT and Leadership Maturity Framework or Barret's Seven Levels of Consciousness, just to name a few). Virtually all of them present variations on the same basic 6-to-8 major structures of increasing complexity (and care).

A simplified version of those major levels (involving just 4 basic stages) has been generically summarized by Wilber as moving from "egocentric" stages (self-focused), to "ethnocentric" stages (group focused), to "worldcentric" stages (encompassing 
all of us, regardless of race, colour, sex or creed), to "integral" (synthesizing all previous stages). These stages are experienced in succession-that is, you have to move through "stage 3" of psychological development before you can reach "stage 4".

Each of these structures of consciousness generate a different cognitive style, morality, self-identity and motivations for the individual and institutions, rules and laws, productive forces, religions, economic systems and technology for society. I use the structure of the hero's journey, a narrative pattern identified by Joseph Campbell (1949), as an apt metaphor to describe the transformational experience that everyone goes through towards becoming all we can become. The hero's journey is the adventure of living and we are the hero destined to take journeys, defeat dragons and find the treasure of our True Self thorough a continuous developmental process (Robledo and Batle 2014).

But how can we influence the process of vertical development in our troubled world, so we can evolve to a more enlightened and conscious society? Based on Kegan's Deliberately Developmental Organizations (2016) [2], Wilber \& DiPerna (2016) [1] examined the notion of a Deliberately Developmental Civilization. Wilber himself (2012), introduced the metaphor of the conveyor belt. He says that the influence of certain institutions and leaders can act as "conveyor belts" for people vertical development, helping them move up the ladder of their personal transformation so they can achieve their own significance. In his book, Integral Spirituality: A Startling New Role for Religion in the Modern and Postmodern World (2006), he argues that religion can serve as the great conveyor belt for humanity. But, in my opinion, the list of influencers can be expanded to include other institutions, and leaders. Political, educational and business leaders and institutions can play a crucial role of levers that can change society, intentionally supporting human transformation through all domains of growth and development [2-7].

\section{References}

1. Wilber K, DiPerna D (2017) Toward a Deliberately Developmental Civilization: Illuminating the Three Key Elements of Spiritual Transformation and Purpose. In: Kuntzelman E, DiPerna D (Eds.), Purpose Rising: A Global Movement of Transformation and Meaning p. 13-28.

2. Kegan R, Lahey L (2016) An Everyone Culture: Becoming a Deliberately Developmental Organization. MA: Harvard Business Review Press, Cambridge, USA.

3. Laloux F (2014) Reinventing Organizations: A guide to creating organizations inspired by the next stage of human consciousness. Brussels, Nelson Parker, Belgium.

4. Robledo MA, Batle J (2015) Transformational tourism as a hero's journey. 20(16): 1736-1748.

5. Wilber K (2006) Integral spirituality: A startling new role for religion in the modern and postmodern world. Boston MA: Shambhala.

6. DiPerna D (2017) Toward a Deliberately Developmental Civilization: Illuminating the Three Key Elements of Spiritual Transformation and Purpose. In: Kuntzelman E, DiPerna D (Eds.), Purpose Rising: A Global Movement of Transformation and Meaning p. 13-28.

${ }^{1}$ Following Wilber and DiPerna (2016), I will use the terms "development" and "transformation" interchangeably (with both of them intimately connected to evolution in general). In both cases, the terms refer to our innate human capacity to both grow (and heal) through predicable, sequential patterns of mental, emotional, and spiritual unfolding.

${ }^{2}$ According to Kegan, a Deliberately Developmental Organization is one that takes a specific approach to growth that gives primary importance to the development of each employee of the organization.

\section{Your next submission with Juniper Publishers} will reach you the below assets

- Quality Editorial service

- Swift Peer Review

- Reprints availability

- E-prints Service

- Manuscript Podcast for convenient understanding

- Global attainment for your research

- Manuscript accessibility in different formats

( Pdf, E-pub, Full Text, Audio)

- Unceasing customer service

Track the below URL for one-step submission https://juniperpublishers.com/online-submission.php 